P-ISSN: 2541-6960; E-ISSN: 2549-8754

Yupa: Historical Studies Journal

Vol. 4 No. 2, 2020 (50-61)

http://jurnal.fkip.unmul.ac.id/index.php/yupa

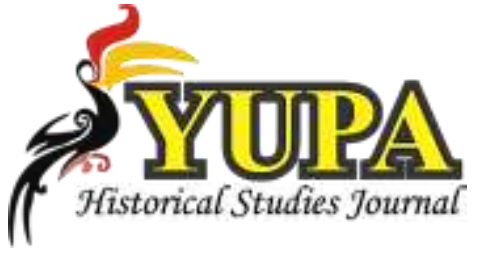

\title{
Kajian Etimologis Kerajaan (Kutai) Martapura di Muara Kaman, Kalimantan Timur
}

\author{
Muhammad Sarip \\ MSI Cabang Kaltim, Jalan Durian 2 No. 91 Samarinda, Indonesia \\ msarip19@gmail.com
}

\begin{tabular}{ccc}
\hline Received & Accepted & Published \\
$18 / 08 / 2020$ & $29 / 09 / 2020$ & $31 / 12 / 2020$ \\
\hline
\end{tabular}

Abstract The first kingdom in the Indonesian Archipelago with its capital at Muara Kaman, East Kalimantan, was known as the Kutai Kingdom. However, the seven yupa inscriptions made in the fifth century $A D$, none of which mention the "Kutai" name or word. This study aims to reveal the real name of dynastic empire founded by Aswawarman, son of Kundungga. The historical research methods used are starting from the heuristic stage, source criticism, interpretation, to historiography. The main source of the research is the Salasilah Kutai book with Malay Arabic script which was completed in 1849. The results showed that the real name of the Mulawarman dynasty which collapsed in 1635 was Martapura, without the word "Kutai" preceded.

Keywords: Kutai, Yupa Inscription, Muara Kaman, Mulawarman, Martapura

Abstrak Kerajaan pertama di Nusantara yang berpusat di Muara Kaman, Kalimantan Timur dikenal publik dengan nama Kerajaan Kutai. Tetapi, dari tujuh prasasti yupa yang dibuat pada abad V Masehi, tidak ada satu pun yang menyebutkan nama atau kata Kutai. Penelitian ini bertujuan mengungkap nama yang sebenarnya dari imperium dinasti yang didirikan Aswawarman putra Kundungga. Metode penelitian sejarah ditempuh dari tahap heuristik, kritik sumber, interpretasi, hingga historiografi. Sumber utama penelitian adalah kitab Salasilah Kutai beraksara Arab Melayu yang selesai ditulis tahun 1849. Hasil penelitian menunjukkan, nama yang sebenarnya dari kerajaan dinasti Mulawarman yang runtuh pada tahun 1635 ini adalah Martapura, tanpa didahului kata Kutai.

Kata Kunci: Kutai, Prasasti Yupa, Muara Kaman, Mulawarman, Martapura 


\section{PENDAHULUAN}

Pada pelajaran sejarah di sekolah dan pemberitaan media publik umumnya mengenal kerajaan tertua di Nusantara dengan nama Kutai. Informasi umum tentang kerajaan Hindu ini bersumber dari prasasti yupa dengan penyebutan tiga generasi pertama. Kundungga, Aswawarman, dan Mulawarman adalah nama raja yang pernah bertakhta pada abad IV hingga V Masehi. Provinsi Kalimantan Timur dikenal dari sejarah ini karena lokasi penemuan sumber sejarahnya, yakni Prasasti Yupa, berada di Muara Kaman, sebuah kecamatan di Kabupaten Kutai Kertanegara.

Selain nama Kutai, beredar pula nama-nama lain bagi kerajaan pertama di Indonesia ini. Ada yang menyebutnya dengan nama: (1) Kerajaan Mulawarman, (2) Kerajaan Kutai Mulawarman, (3) Kerajaan Martadipura, (4) Kerajaan Kutai Martadipura, (5) Kerajaan Kutai ing Martadipura, (6) Kerajaan Kutai Mulawarman ing Martadipura. Keenam nama ini tidak ada yang mempunyai sumber sejarah terverifikasi.

Dari ketujuh prasasti yupa yang ditemukan pada 1879 dan 1940, sebenarnya tidak satu pun yang menyebut nama kerajaan di Muara Kaman dengan nama Kutai. Nama Kutai yang disematkan sesungguhnya hanya pendekatan atau asumsi berdasarkan lokasi penemuan prasasti yupa di wilayah Kesultanan Kutai. Tim Penyusun Sejarah Nasional Indonesia dalam buku Jilid 2 mengungkapkan, nama Kutai digunakan oleh para peneliti sejak zaman Belanda untuk menamakan kerajaan Dinasti Mulawarman berdasarkan lokasi penemuan prasasti yupa di wilayah Kutai (Poesponegoro \& Notosusanto, 2008: 43).

Sejarawan dan ilmuwan sastra Melayu, Constantinus Alting Mees, lebih dulu menegaskan perihal nama Kutai yang bukan kepunyaan Dinasti Mulawarman. Dalam disertasinya, Mees menyatakan bahwa koloni Hindu di Muara Kaman itu tidak pernah dinamakan Kutai. Nama Kutai baru dikenal sejak Aji Batara Agung Dewa Sakti mendirikan kerajaan di muara Sungai Mahakam pada penghujung abad ke-13 (Mees, 1935: 12).

Literasi mengenai Kerajaan Martapura masih minim. Padahal, di tanah Kutai terdapat naskah klasik beraksara Arab Melayu yang bisa diteliti sebagai sumber historiografi tradisional. Naskah itu bernama Surat Salasilah Raja dalam Negeri Kutai Kertanegara, yang selesai ditulis oleh Khatib Muhammad Thahir pada 30 Rabiul Awal 1265 Hijriah atau 24 Februari 1849. Kitab yang sering disebut "Salasilah Kutai" ini disimpan di Perpustakaan Negeri Berlin, Jerman.

Kitab Salasilah Kutai merupakan sumber historiografi untuk sebuah kerajaan yang berdiri di Jaitan Layar pada tahun 1300 Masehi. Kerajaan ini bernama Kutai Kertanegara. Lokasinya di hilir Sungai Mahakam, yang kini dikenal dengan nama Desa Kutai Lama, Kecamatan Anggana, Kabupaten Kukar. Pada pertengahan abad ke-14 Kutai Kertanegara 
dan Dinasti Mulawarman menjalin hubungan bilateral sebagai kerajaan yang setara yang sama-sama berdaulat. Pada perkembangan tiga abad berikutnya, Kutai Kertanegara menyerang Muara Kaman dan menganeksasi wilayah Dinasti Mulawarman.

Penelitian ini bertujuan mengungkap nama yang sebenarnya dari kerajaan di Muara Kaman Kalimantan Timur yang berpredikat sebagai imperium pertama di Nusantara. Hasil penelitian diharapkan dapat berkontribusi bagi pengetahuan Sejarah Nasional Indonesia sekaligus meluruskan informasi sejarah lokal Kalimantan Timur yang selama ini lebih banyak tercampur dengan kisah khayal atau dongeng serta hoaks.

Penelitian ini menggunakan sumber primer kitab Salasilah Kutai beraksara Arab Melayu. Berkas digital kitab ini bisa diakses dari situs Perpustakaan Berlin-Jerman. Dalam rekonstruksi sejarah, penulis juga merujuk referensi dan hasil riset yang bermutu sebagai karya historiografi. Literatur yang dijadikan rujukan adalah pustaka-pustaka yang mempunyai kedalaman analisis dari para ahli sejarah yang diterbitkan sejak zaman Kolonial Belanda.

\section{METODE PENELITIAN}

Penyusunan karya tulis ini menempuh metode penelitian sejarah sebagaimana standar ilmu sejarah. Pertama, heuristik, yaitu pengumpulan sumber sejarah. Penulis memperoleh pustaka klasik karya peneliti Belanda, sebagian dari situs internet penyedia berkas digital, sebagian dari bantuan kolega. Dalam memahami makna tulisan berbahasa Belanda, penulis menggunakan aplikasi terjemahan Google Translate serta merujuk terjemahan yang dikutip dalam pustaka berbahasa Indonesia dan Melayu. Selain itu, penulis meminta bantuan kolega yang bisa berbahasa Belanda. Adapun dalam membaca aksara Arab Melayu pada kitab Salasilah Kutai, penulis mempunyai kemampuan dasar baca-tulis aksara Jawi dari warisan pelajaran kakek penulis sewaktu kecil dahulu. Sementara itu, sebagian buku-buku cetak, terutama yang terbitan kontemporer dan mutakhir, penulis mendapatkannya dengan membeli.

Kedua, kritik sumber, yaitu melakukan verifikasi terhadap sumber sejarah dengan kritik ekstern dan kritik intern. Sumber-sumber dari situs internet diverifikasi keaslian/keabsahan literaturnya serta tingkat kredibilitas informasinya.

Ketiga, interpretasi, yaitu penafsiran atau pemberian makna atas fakta dan sumber sejarah. Pada tahap ini, peristiwa sejarah dianalisis bagaimana prosesnya dan bagaimana memahami proses terjadinya sejarah tersebut. 
Keempat, historiografi, yaitu penulisan sejarah dengan memuat tiga substansi yaitu pendahuluan, hasil penelitian, dan simpulan dengan pembahasan yang memiliki retorik dan bahasa yang mudah dipahami publik secara umum.

Penulisan karya ini menggunakan metode deskripsi analitis sehingga karya tulis ini lebih dari sekadar narasi peristiwa masa silam. Ada penelusuran mendalam terhadap riwayat tempo dulu.

\section{HASIL DAN PEMBAHASAN}

\section{Asal Usul Nama Kutai}

Prasasti yupa yang ditemukan di Muara Kaman, Kalimantan Timur merupakan bukti eksistensi kerajaan tertua di Nusantara. Peneliti pertama prasasti yupa, yakni Prof. Johan Hendrik Caspar Kern, menetapkan tarikh pembuatan prasasti yupa pada kisaran tahun 400 Masehi (Vogel, 1917: 185). Sementara ahli epigrafi Louis Charles Damais menetapkan waktunya pada tahun 425 M (Kemdikbud, 2014). Pendapat lain dikemukakan Edhie Wurjantoro sebagai penulis Subbab "Mulawarman (Kutai) di Kalimantan Bagian Timur" pada Bab "Munculnya Kerajaan Tertua di Nusantara" dalam buku Indonesia dalam Arus Sejarah Jilid 2: Kerajaan Hindu-Buddha. Dosen Arkeologi UI ini menetapkan tarikh prasasti yupa pada pertengahan abad ke-5 atau kisaran tahun 450 (Wurjantoro dalam Abdullah, 2012: 42).

Rajanya yang pertama, yakni Kundungga (ejaan kun-dung-ga menggunakan $n$ pada suku kata pertama) adalah orang asli Kalimantan, bukan imigran dari Champa atau India. Hindu menjadi agama resmi kerajaan setelah putra Kundungga yang bernama Aswawarman menjadi seorang Hindu melalui perantaraan brahmana. Penerus takhta setelah Aswawarman, yakni putranya yang bernama Mulawarman, mengalami masa kejayaan. Upacara monumetal dengan persembahan komoditas sumber daya alam bervolume besar dicatat dalam prasasti yupa. Brahmana dari India didatangkan untuk menorehkan aksara Pallawa berbahasa Sanskerta pada prasasti (Vogel, 1917: 185-197).

Nama kerajaan tertua di Nusantara yang umumnya diketahui oleh khalayak adalah Kutai. Tim Penyusun Sejarah Nasional Indonesia mengungkapkan, nama Kutai digunakan oleh para peneliti sejak zaman Belanda untuk menamakan kerajaan Dinasti Mulawarman berdasarkan lokasi penemuan prasasti yupa di wilayah Kesultanan Kutai (Poesponegoro \& Notosusanto, 2008: 43). Tetapi, prasasti yupa sendiri tidak menyebutkan nama kerajaannya dengan Kutai. 
Peneliti sejarah Kutai, C.A. Mees, menegaskan perihal nama Kutai yang bukan kepunyaan Dinasti Mulawarman. Dalam disertasinya, ahli sastra dan sejarah Melayu itu menyatakan bahwa koloni Hindu di Muara Kaman tidak pernah dinamakan Kutai. Nama Kutai baru dikenal sejak Aji Batara Agung Dewa Sakti mendirikan kerajaan di muara Sungai Mahakam pada penghujung abad ke-13 (Mees, 1935: 12). Kemudian, nama Kutai juga tercantum dalam kitab Negarakretagama yang ditulis Mpu Prapanca tahun 1365. Prapanca menyebut Kute setelah Tunjung sebagai satu dari (Muljana, 1965: 69).

Ilmuwan lainnya, Solco Walle Tromp, juga berpendapat senada mengenai nama Kutai. Tromp yang pernah menjabat Asisten Residen Borneo Timur itu pada penghujung abad ke-19 mengungkap asal usul kata Kutai dalam karya risetnya sebagaimana berikut ini.

"Spoedig na het huwelijk werd Poetěri Karang Mĕlěnoe zwanger. Zooals gewoonlijk, had zij in die gezegende omstandigheden lust in bijzondere schoteltjes, en om daaraan te kunnen voldoen ging Adji Batara Agoeng Dewa Sakti met zijn blaaspijp op de jacht. Hij kreeg echter niets dan een "toepei" (eekhoorn), die van een "pětei" (boom met zeer stinkende vruchten), aan het "pantei" (strand) staande, ni de "koempei" (riet) viel. Die toevallige combinatie van "toepei", "pětei", "pantei" en "koempei", vond Adji Batara Agoeng Dewa Sakti zóó treffend, dat hij op de plaats der "koempei" een nieuwe "pedalaman" stichtte en deze Koetei noemde." (Tromp, 1888: 8-9)

Tromp mendeskripsikan, istri Aji Batara Agung Dewa Sakti, yakni Putri Karang Melenu, sedang hamil dan mengidam makanan khusus. Lalu, Aji Batara Agung berburu dengan sumpit. Namun, ia tidak memperoleh apa-apa selain tupai yang jatuh dari pohon petai. Lokasinya di pantai yang ditumbuhi kumpai atau rumput ilalang. Menyaksikan peristiwa ini, Adji Batara Agung terkesima lalu membuka sebuah permukiman. Dari kombinasi kata tupai, petai, pantai, dan kumpai, ia mencetuskan nama Kutai.

Narasi tentang asal usul nama Kutai terdapat dalam kitab Surat Salasilah Raja dalam Negeri Kutai Kertanegara yang selesai ditulis oleh Khatib Muhammad Thahir pada 1849. Manuskrip klasik beraksara Arab Melayu yang sering diringkas namanya menjadi Salasilah Kutai ini, sebagaimana naskah Melayu tradisional lainnya, memang mengandung mitologis selain muatan sejarah. Namun, dengan metode sejarah, kitab ini dapat dijadikan sumber penelitian sejarah. Selain Tromp dan Mees, sejararawan lain yang mempergunakan Salasilah Kutai sebagai sumber historiografi adalah Bernard Hubertus Maria Vlekke. Vlekke mengungkap indikasi kelanjutan dinasti Mulawarman dalam bukunya yang legendaris, Nusantara: A History of Indonesia. Menurut Vlekke menulis, walaupun sama sekali tanpa prasasti, tampaknya imperium Mulawarman terus ada, karena pada zaman jauh kemudian ada kerajaan yang kemudian berganti kesultanan Kutai 
di dekat muara Sungai Mahakam. Kesultanan ini kemudian yang membuat tawarikh atau catatan riwayat adanya kerajaan di Muara Kaman (Vlekke, 1961: 31-32).

Pada masa mutakhir, ada pendapat dari Prof. Abdul Hadi, Guru Besar Filsafat Islam Universitas Paramadina Jakarta, yang mengklasifikasikan Salasilah Kutai sebagai sastra sejarah (Hadi dalam Abdullah, 2012: 215). Pernyataan ini termuat dalam buku Indonesia dalam Arus Sejarah Jilid 3: Kedatangan dan Peradaban Islam. Dalam buku yang disponsori Kemdikbud ini, Abdul Hadi menulis bab yang berjudul "Tradisi Sastra dan Kebahasaan”.

Teks Arab Melayu Salasilah Kutai yang memuat asal usul nama Kutai dapat disimak pada gambar berikut ini.

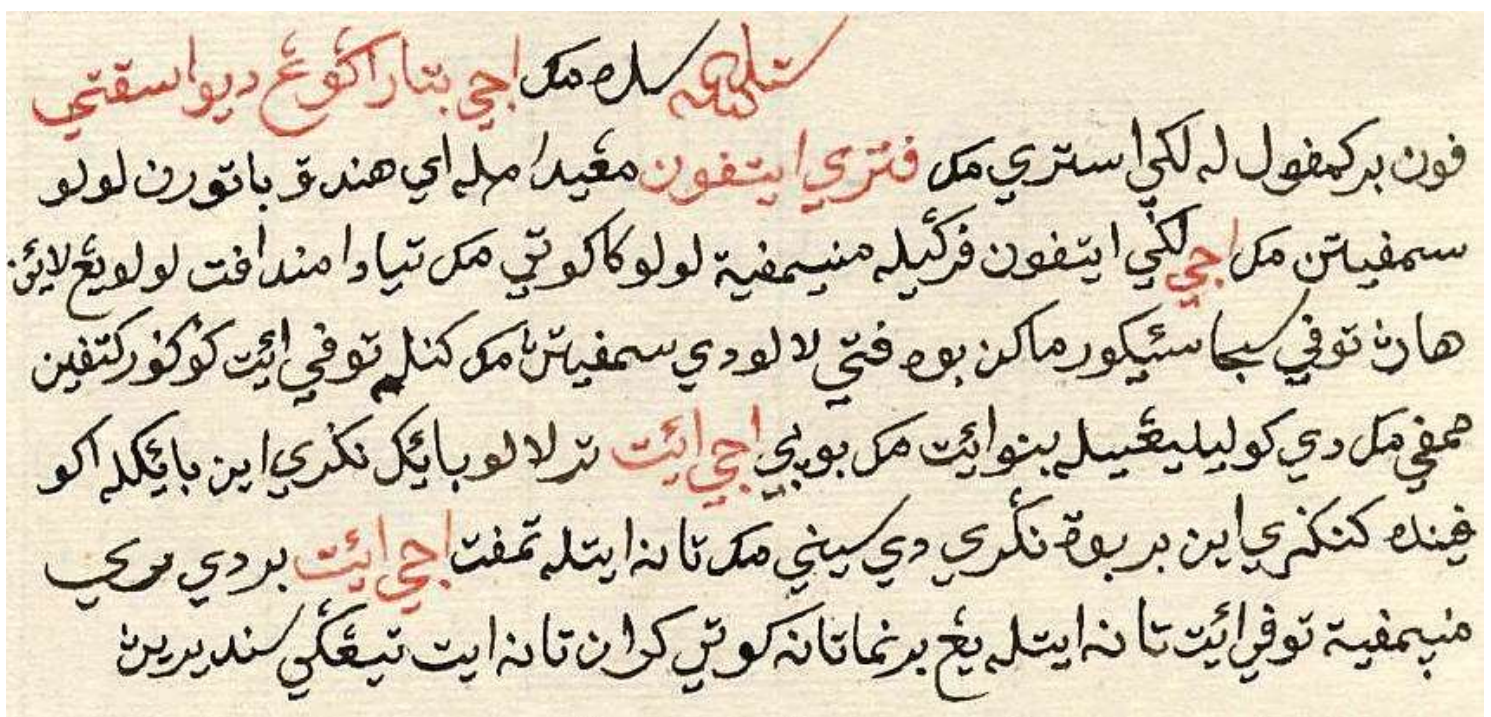

Gambar 1. Teks Arab Melayu mengenai asal usul nama Kutai yang tertulis dalam kitab Salasilah Kutai, halaman ke-41 (huruf berwarna merah merupakan perwarnaan yang orisinal dari penulis kitab).

Sumber: Surat Salasilah Raja dalam Negeri Kutai Kertanegara, 1849

Transliterasi dari teks Arab Melayu di atas adalah sebagai berikut.

"Setelah sudah maka Aji Batara Agung Dewa Sakti pun berkumpullah laki-istri. Maka putri itu pun mengidamlah ia hendak baturan lulu sumpitan. Maka Aji laki itu pun pergilah menyumpit lulu ke Kutai. Maka tiada mendapat lulu yang lain. Hanya tupai saja seekor makan buah petai. Lalu disumpitnya maka kenalah tupai itu, gugur ke tepian mampi. Maka dikelilinginyalah benua itu. Maka bunyi Aji itu, "Terlalu baik negeri ini. Baiklah aku pindah ke negeri ini, berbuat negeri di sini." Maka tanah itulah tempat Aji itu berdiri menyumpit tupai itu, tanah itulah yang bernama Kutai, karena tanah itu tinggi sendirinya."

Berdasarkan sumber primer Salasilah Kutai dan analisis para ilmuwan, terbukti bahwa nama Kutai bukanlah nama yang sebenarnya dari Dinasti Mulawarman. Kutai adalah nama kerajaan yang berdiri mula-mula di Jaitan Layar, sebuah lokasi di hilir Sungai Mahakam, sebelum ibu kotanya dipindahkan ke Jembayan dan Tenggarong (Sarip, 2018: 
36). Kini, tempat awal berdirinya di selatan Kota Samarinda itu dikenal dengan nama administratif Desa Kutai Lama. Dari toponimi Kutai Lama ini juga mengindikasikan bahwa Kutai yang "terlama” berada pada jejak Kerajaan Kutai Kertanegara, bukan pada Dinasti Mulawarman di Muara Kaman.

\section{Antara Martapura dan Martadipura}

Setelah nama Kutai untuk kerajaan di Muara Kaman diketahui kekeliruannya, masalah berikutnya adalah nama-nama tambahan atau pelengkap yang mengiringi toponimi Kerajaan Kutai. Ada yang menyebutkan Kutai Mulawarman, Kutai Martadipura, Kutai Martapura, dan sebagainya. Penamaan Mulawarman jelas keliru karena Mulawarman merupakan nama raja ketiga, bukan nama imperiumnya. Adapun nama Martadipura, ini sangat populer. Kata Martadipura dipakai sebagai nama jembatan terpanjang di Kabupaten Kutai Kartanegara (Kukar)/. Lalu, ada tambahan ing Martadipura pada ujung nama Kesultanan Kutai Kertanegara yang dihidupkan kembali sejak 2001. Selain itu, beredar pula nama Martapura.

Kerajaan Kutai yang disebut sebagai kerajaan tertua di Nusantara itu nama sebenarnya adalah Martapura, bukan Martadipura, dan tanpa embel-embel Kutai. Hal ini karena nama Kutai baru muncul pada akhir abad ke-13 Masehi yang dicetuskan oleh Aji Batara Agung Dewa Sakti, sang pendiri Kerajaan Kutai Kertanegara. Martapura dan Kutai Kertanegara adalah dua imperium yang berbeda. Martapura berkedudukan di hulu Sungai Mahakam yakni di Muara Kaman. Pendiri dinastinya adalah Aswawarman putra Kundungga. Adapun ibu kota Kutai Kertanegara lebih dekat ke muara Mahakam, berpindah-pindah dari Jaitan Layar, Tepian Batu, Jembayan, hingga Tenggarong (Sarip, 2018: 36). Rincian perbedaan antara kedua kerajaan di timur Kalimantan itu tersaji dalam tabel berikut ini.

Tabel 1. Perbedaan antara Kerajaan Martapura dan Kutai Kertanegara.

\begin{tabular}{|c|c|c|c|}
\hline No. & Perbedaan & Martapura & Kutai Kertanegara \\
\hline 1 & Tarikh berdiri & \pm 400 Masehi & 1300 Masehi \\
\hline 2 & Tahun keruntuhan & 1635 & 1960 \\
\hline 3 & Sebab runtuh & $\begin{array}{l}\text { Agresi militer dan unifikasi } \\
\text { oleh Kerajaan Kutai } \\
\text { Kertanegara* }\end{array}$ & $\begin{array}{l}\text { Regulasi Pemerintah RI } \\
\text { (UU No. } 27 \text { Tahun 1959) }\end{array}$ \\
\hline 4 & Durasi eksistensi & \pm 12 Abad & $61 / 2$ Abad (660 tahun) \\
\hline 5 & Ibu kota & Muara Kaman & $\begin{array}{l}\text { Jaitan Layar/Kutai Lama (1300-1360); } \\
\text { Tepian Batu/Kutai Lama (1360-1732); } \\
\text { Pemarangan/Jembayan (1732-1782); } \\
\text { Tenggarong (1782-1960) }\end{array}$ \\
\hline 6 & Pendiri dinasti & $\begin{array}{l}\text { Aswawarman putra } \\
\text { Kundungga }\end{array}$ & Aji Batara Agung Dewa Sakti \\
\hline 7 & Raja populer & Mulawarman & Aji Muhammad Sulaiman \\
\hline
\end{tabular}




\begin{tabular}{clll}
\hline No. & \multicolumn{1}{c}{ Perbedaan } & \multicolumn{1}{c}{ Martapura } & \multicolumn{1}{c}{ Kutai Kertanegara } \\
\hline 8 & Raja terakhir & Dermasatia & Aji Muhammad Parikesit \\
\hline 9 & Agama & Hindu corak India & $\begin{array}{l}\text { Hindu corak lokal (1300-1575); } \\
\text { Islam (1575-1960) }\end{array}$ \\
\hline \multirow{2}{*}{10} & $\begin{array}{l}\text { Sumber utama } \\
\text { sejarah }\end{array}$ & $\begin{array}{l}\text { Tujuh Prasasti Yupa } \\
\text { beraksara Pallawa, } \\
\text { berbahasa Sanskerta }\end{array}$ & $\begin{array}{l}\text { Kitab Surat Salasilah Raja dalam } \\
\text { Negeri Kutai Kertanegara, beraksara } \\
\text { Arab-Melayu }\end{array}$ \\
\hline
\end{tabular}

Sumber: diolah dari berbagai sumber (Sarip, 2020)

Kerajaan Martapura yang berdiri pada kisaran tahun 400 Masehi itu akhirnya runtuh pada 1635 akibat diagresi oleh pasukan Kutai Kertanegara yang dipimpin Pangeran Sinum Panji Mendapa. Kutai Kertanegara pun menambahkan nama kerajaannya dengan Martapura sehingga menjadi Kutai Kertanegara ing Martapura. Informasi nama Martapura ini terdapat dalam kitab Salasilah Kutai. Nama ing Martapura disematkan sebagai pelengkap nama raja Kutai Kertanegara yang menaklukkan penguasa takhta terakhir di Muara Kaman.

Perhatikan teks kitab Salasilah Kutai pada Gambar 2. Fokus pada tiga frasa tulisan Arab Melayu yang bertinta merah. Dalam hal ini, warna merah memang berasal dari penulis kitab, bukan editan gambar.

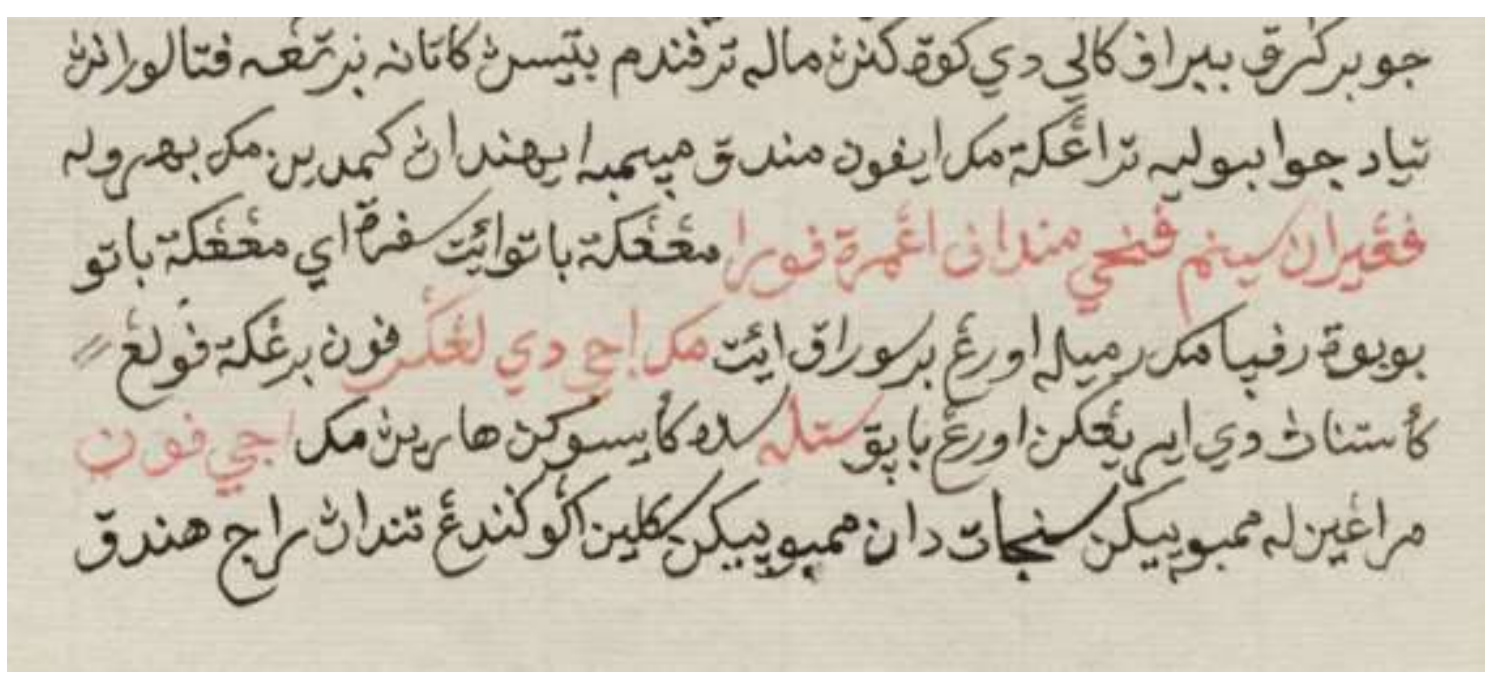

Gambar 2. Halaman kitab Salasilah Kutai yang memuat kata Martapura (huruf berwarna merah merupakan perwarnaan yang orisinal dari penulis kitab). Sumber: Surat Salasilah Raja dalam Negeri Kutai Kertanegara, 1849.

Pada bagian akhir frasa berwarna merah terdapat susunan huruf alif, ng, mim, ra, $t a, f a, w a w, r a$. Tidak ada huruf dal di antara huruf ta dan $f a$. Dengan demikian, susunan ini dieja dengan ing Martapura, bukan ing Martadipura.

Lantas, dari mana asal usul nama Martadipura? Nama Martadipura sebagai perubahan dari kata Martapura baru muncul pada era 1980-an. Bupati Kutai periode 1965-1979, Ahmad Dahlan, mengungkapkan, idenya berasal dari Drs. Anwar 
Soetoen, seorang pejabat Pemerintah Daerah Kabupaten Tingkat II Kutai. Soetoen berpikiran bahwa antara kata marta dan pura perlu disisipkan kata depan di sebagai pengganti ing. Menurutnya, kata depan di sama arti dengan kata Jawa Kawi ing. Dahlan mengungkap kasus ini dalam bukunya tentang Salasilah Kutai (Adham, 1981: 13-14).

Pemikiran "Martadipura" ini tidak bisa dibenarkan karena mengubah nama yang sudah jelas tertulis dalam kitab Surat Salasilah Raja dalam Negeri Kutai Kertanegara. Perubahan Martapura menjadi Martadipura tidak sekadar menambahkan suku kata di, tapi juga mengakibatkan kerancuan makna istilah. "Pendapat ini jelas dipaksakan dan tidak tepat," kata Dwi Cahyono dan Gunadi, dua orang ahli arkeologi yang mengkaji arkeologi Kutai Martapura. Apabila kata depan ing digunakan, sementara antara kata Marta dan Pura disisipi kata depan di (bahasa Melayu)-yang serupa arti dengan ing-berarti terjadi pengulangan (Cahyono dan Gunadi, 2007: 37). Fakta lain, di Muara Kaman terdapat kawasan purbakala yang bernama Gunung Martapura. Begitu pula stempel Sultan Kutai yang pernah terpublikasi pada tahun 1999 tetap menggunakan nama Martapura sebagai tambahan, bukan Martadipura seperti yang diinginkan Soetoen.

Nama Martapura digunakan oleh para peneliti dan ilmuwan sejak dulu. Contohnya, Mohammad Asli Amin menyusun skripsi pada 1968 dengan judul "Pertumbuhan Kerajaan Kutai Kertanegara ing Martapura". Begitu pula Ita Syamtasiyah Ahyat, sejarawan Universitas Indonesia. Ia menerbitkan buku yang berjudul Kesultanan Kutai 1825-1910 Perubahan Politik dan Ekonomi Akibat Penetrasi Kekuasaan Belanda. Di dalamnya, pengajar Fakultas Ilmu Pengetahuan Budaya UI ini menuliskan nama Martapura, bukan Martadipura (Ahyat, 2012: 9).

Dengan demikian, jelaslah kekeliruan nama Martadipura untuk menyebut kerajaan yang puncak kejayaannya pada masa Maharaja Mulawarman ini. Berdasarkan uraian yang dipaparkan di atas, maka nama yang benar adalah Martapura, bukan Martadipura.

\section{Relasi Martapura-Muara Kaman dan Martapura-Banjar}

Masalah berikutnya, apakah makna nama Martapura? Ada yang menyebutkan bahwa kata marta berarti permata atau intan, sedangkan pura berarti kota atau istana. Namun, penetapan makna kata ini perlu verifikasi lebih lanjut. Perubahan kata permata menjadi marta terlalu jauh perbedaannya. Yang lebih dekat, marta berasal dari akar kata amarta atau amerta, yang dalam bahasa Sanskerta berarti kehidupan. Jadi, Martapura berarti kota kehidupan.

Kemudian, adakah kaitan antara Martapura di timur Kalimantan dengan Kota Martapura di selatan Kalimantan? Apakah keduanya berhubungan atau hanya kesamaan nama yang tidak disengaja? Ada petunjuk dari Prof. Sambas Wirakusumah dkk yang 
menyusun buku Sejarah Daerah Kalimantan Timur tahun 1977. Diceritakan, setelah Kerajaan Martapura di Muara Kaman jatuh ke dalam kekuasaan Kutai Kertanegara, ada seorang bekas menteri Kerajaan Martapura yang menyingkir ke Banjarmasin. Namanya Nanang Baya (Wirakusumah dkk, 1978: 21). Dalam kaitan ini, Banjarmasin sejak 1526 merupakan ibu kota Kesultanan Banjar. Kemudian, pada 1612 Banjar memindahkan pusat pemerintahannya di lokasi yang bernama Kayutangi-Martapura (Eisenberger, 1936: 6). Pemindahan ibu kota dilakukan oleh Marhum Panambahan atau Sultan Musta'in Billah (Saleh dkk, 1978: 33).

Penulis menelusuri kitab Salasilah Kutai. Ternyata, nama yang tertera bukan Nanang Baya, melainkan Ki Narangbaya. Versi Sambas dkk juga berbeda dengan Salasilah Kutai mengenai arah pengungsiannya. Salasilah Kutai menyebut, usai kekalahan Muara Kaman, Ki Narangbaya pergi ke Kota Bangun (Thahir, 1849: 112). Dari Muara Kaman ke Kota Bangun berjarak \pm 20 kilometer ke arah selatan atau hulu Mahakam. Tidak ada penyebutan ia mengungsi ke Banjarmasin. Namun, terdapat hal yang unik mengenai nama Narangbaya. Dalam Hikayat Banjar ada penyebutan tokoh bernama Kiai Narangbaja yang hidup sezaman dengan Marhum Panambahan di Kerajaan Banjar. Narangbaja termasuk satu di antara rombongan yang diutus Sultan Banjar untuk berangkat ke Kesultanan Mataram di Pulau Jawa mengantarkan intan dan hadiah lainnya (Ras, 1990: 352). Peristiwanya terjadi pada tahun 1641 (Eisenberger, 1936: 8). Ini berarti berselang enam tahun setelah runtuhnya Kerajaan Martapura. Jadi, ada kemiripan nama Narangbaya di dua lokasi, Martapura Muara Kaman dan Martapura Banjar.

Lantas, apakah Narangbaja di Banjar ini merupakan orang yang sama dengan Narangbaya di Muara Kaman? Kemungkinan itu ada, dengan hipotesis bahwa Narangbaya setelah pindah dari Muara Kaman ke Kota Bangun, melanjutkan perjalanan ke selatan sampai tiba Kayutangi-Martapura. Lalu, sebagai mantan pembesar Kerajaan Martapura, Narangbaya mendapatkan kemudahan untuk menjadi pengabdi di Kesultanan Banjar.

Relasi antara Kutai dengan Banjar juga ada dinarasikan dalam kejadian lain. Raja Makota adalah kakek dari Pangeran Sinum Panji Mendapa ing Martapura. Lalu, ada seorang cicit atau keturunan dari Raja Makota yang bernama Aji Bangbang. Aji Bangbang ini terhitung keponakan atau cucu dari Pangeran Sinum Panji Mendapa. Salasilah Kutai mewartakan bahwa Aji Bangbang beristri ke Banjar. Pasangan ini memperoleh keturunan yang dinamai Pangeran Purbaya (Thahir, 1849: 113). Namun, apakah persamaan nama Martapura antara kerajaan di Kalimantan Timur dan ibu kota Kesultanan Banjar di Kalimantan Selatan memiliki hubungan inspirasi, belum dapat dipastikan realitasnya karena memerlukan sumber sejarah lain yang terverifikasi. 


\section{KESIMPULAN}

Yang tersohor bukan berarti benar. Yang kurang dikenal belum tentu salah. Kebenaran tidak diukur dari popularitas dan suara terbanyak. Kebenaran ditimbang dengan fakta dan kaidah ilmiah. Nama imperium Hindu tertua di daratan timur Kalimantan sebenarnya tidak tercantum dalam prasasti yupa. Asumsi nama Kutai yang disematkan untuk kerajaan Dinasti Mulawarman bukan pilihan yang tepat karena itu adalah nama kerajaan lain yang berdiri di muara Sungai Mahakan sekitar sembilan abad setelah prasasti yupa didirikan. Naskah historiografi tradisional Salasilah Kutai menyebut istilah ing Martapura pada akhir nama raja Kutai Kertanegara yang menganeksasi Muara Kaman. Berdasarkan petunjuk ini, ditetapkan nama Kerajaan Martapura sebagai identitas imperium. Martapura bermakna kota kehidupan, berasal dari bahasa Sanskerta, amartapura.

\section{REFERENSI}

Abdullah, Taufik \& A.B. Lapian (Ed.) (2012a). Indonesia dalam Arus Sejarah Jilid 2: Kerajaan Hindu-Buddha. Jakarta: Ichtiar Baru van Hoeve.

. (2012b). Indonesia dalam Arus Sejarah Jilid 3: Kedatangan dan Peradaban Islam. Jakarta: Ichtiar Baru van Hoeve.

Adham, D. (1981). Salasilah Kutai. Jakarta: Departemen Pendidikan dan Kebudayaan.

Ahyat, Ita Syamtasiyah. (2013). Kesultanan Kutai 1825-1910: Perubahan Politik dan Ekonomi Akibat Penetrasi Kekuasaan Belanda. Tangerang Selatan: Serat Alam Media, 2013.

Amin, M. Asli, dkk. (1975). Dari Swapraja ke Kabupaten Kutai. Tenggarong: Pemerintah Daerah Kabupaten Kutai Kalimantan Timur.

Cahyono, M. Dwi \& Gunadi. (2007). Kajian Arkeologi Sejarah Kerajaan Kutai Martapura. Tenggarong: Badan Penelitian dan Pengembangan Daerah Kabupaten Kutai Kartanegara.

Chhabra, B. Ch. (1965). Expansion of Indo-Aryan Culture During Pallava Rule. New Delhi: Munshi Ram Manohar Lal Oriental Publishers \& Booksellers Nai Sarak. https://archive.org/details/in.gov.ignca.41979. Diakses 29 April 2020.

Eisenberger, J. (1936). Kroniek der Zuider en Oosterafdeeling van Borneo. Banjarmasin: Liem Hwat Sing.

Hurgronje, Snouck. (1888). "Nog Iets Over de Salasila van Koetei." Bijdragen tot de Taal-, Land- en Volkenkunde van Nederlandsch-Indië, Deel 37. 109-120.

Keputusan Menteri Pendidikan dan Kebudayaan Republik Indonesia Nomor 279/M/2014 tentang Tujuh Prasasti Yupa Koleksi Museum Nasional Nomor Inventaris D.2A, D.2B, D.2C, D.2D, D.175, D.176, dan D.177 sebagai Kawasan Cagar Budaya Peringkat Nasional. https://jdih.kemdikbud.go.id/arsip/Kepmendikbud\%20Nomor\%20455-M2019.pdf. Diakses 21 April 2020.

Kern, W. (1956). Commentaar op de Salasilah van Koetai. 's-Gravenhage: Martinus Nijhoff. 
Knappert, S.C. (1905). "Beschrijving Van De Onderafdeeling Koetei.” Bijdragen tot de taal-, land- en volkenkunde, Volume 58, Issue 1. 575-654.

Mees, Constantinus Alting. (1935). De Kroniek van Koetai Tekstuitgave Met Toelichting. Santpoort: N.V. Uitgeverij.

Muljana, Slamet. (2005). Menuju Puncak Kemegahan (Sejarah Kerajaan Majapahit). Diterbitkan pertama kali oleh Balai Pustaka, 1965. Yogyakarta: LkiS. . (2006). Tafsir Sejarah Nagara Kretagama. Diterbitkan pertama kali oleh Bhatara Karya Aksara, 1979. Yogyakarta: LkiS.

Poesponegoro, Marwati Djoened \& Nugroho Notosusanto (Ed.). (2008). Sejarah Nasional Indonesia II Zaman Kuno (Awal M-1500 M), Edisi Pemutakhiran. Jakarta: Balai Pustaka.

Ras, Johannes Jacobus. (1990). Hikayat Banjar. Diterjemahkan oleh Siti Hawa Salleh. Kuala Lumpur: Dewan Bahasa dan Pustaka.

Saleh, M. Idwar, dkk. (1978). Sejarah Daerah Kalimantan Selatan. Jakarta: Departemen Pendidikan dan Kebudayaan Proyek Inventarisasi dan Dokumentasi Kebudayaan Daerah 1977/1978.

Sarip, Muhammad. (2018). Dari Jaitan Layar sampai Tepian Pandan Sejarah Tujuh Abad Kerajaan Kutai Kertanegara. Samarinda: RV Pustaka Horizon.

Thahir, Khatib Muhammad. (1849). Surat Salasilah Raja dalam Negeri Kutai Kertanegara. (Aksara Arab Melayu). http://resolver.staatsbibliothek-berlin.de/SBB00019D9A0000 0000. Diakses 30 Juli 2019.

Tromp, S.W. (1888). Uit de Salasila Van Koetei. 's-Gravenhage: Martinus Nijhoff.

Vlekke, Bernard H.M. 2008. Nusantara Sejarah Indonesia. Diterjemahkan dari Nusantara: A History of Indonesia, 1961. Jakarta: Kepustakaan Populer Gramedia.

Vogel, J.Ph. (1918) "The Yupa Inscription of King Mulawarman, from Koetei (East Borneo)". BKI 74. 167-235.

Wirahadikusumah, Sambas dkk. (1978). Sejarah Daerah Kalimantan Timur. Jakarta: Departemen Pendidikan dan Kebudayaan Proyek Inventarisasi dan Dokumentasi Kebudayaan Daerah 1976/1977. 